\title{
Traditional Views and Attitude Toward Waste and Rivers in Indonesia: Challenges of Cleaning Up the Indonesia Polluted Enviroment
}

\author{
Peter Suwarno ${ }^{1}$, and Nurhayati Nurhayati ${ }^{2 *}$ \\ ${ }^{1}$ School of International Letters and Cultures, Arizona State University, Tempe - Arizona \\ ${ }^{2}$ Master Program of Linguistics, Faculty of Humanities, Diponegoro University, Semarang - \\ Indonesia
}

\begin{abstract}
Since water is an indispensable part of humanity, human communities settle near water sources, and one of the most popular water sources is a river. In the past millennial, around $80 \%$ of Javanese communities were located near rivers. However, traditional views, attitudes, and behavior during the development and urbanization era and lack of political will have compromised sustainable uses of rivers choked with pollution from industrial and neighborhood wastes. This paper will discuss the stories of pollution and waste management that have led to Indonesia being one of the most polluted nations by looking at traditional sociocultural views of waste and rivers and efforts to deal with the problems of garbage. This study is mainly based on various data from previous research, NGO and government programs, and interviews with local community members and leaders. In addition to the challenges of garbage disposal and cleaning up Indonesian rivers, this study will conclude with suggestions on how to change people's attitudes and behavior and government programs to create long-term sustainable and participative waste management efforts in Indonesia.
\end{abstract}

\section{Introduction}

Modern lifestyle has contributed to ever-increasing consumption driven by a consumerist culture that results in an upsurge of waste production, polluting the air and water and degrades the environment. As the essential life-sustaining water resource system that humans depend on, rivers have also become the most common dumping grounds for modern and often toxic wastes. In the past millennium, about $80 \%$ of Javanese communities were located near rivers. However, their traditional views, attitudes, and behaviour have changed during the era of development, urbanization, modern consumerist lifestyles [1]. Various government and community efforts have minimal success in dealing with issues of wastes disposal in Indonesia that is infamously known in the world. It takes a drastic change in socio-political will from all stakeholders to reverse the garbage dumping habits causing compromised uses of rivers that have been choked with contamination from industrial and neighbourhood wastes.

This paper attempts to describe the challenges of waste management that have damaged the environment in Indonesia. It will examine the efforts by the communities and governments in dealing with waste management, especially the government regulations, the signs and images describing the problem of garbage management and the interviews containing the reactions of the people dumping garbage into the rivers. It will attempt to

\footnotetext{
*Corresponding author: nurhayati@live.undip.ac.id
} 
answer why these efforts have limited success, using previous studies and some sociopsychological theories that could help explain people's attitudes and behaviour. Examining these data and the theories will hopefully provide some reasons for the challenges and possible ways to resolve them.

\section{Literature review and theory}

There have been numerous studies on the issues of environmental and river pollution and the efforts to deal with them. The contamination from haphazard garbage-dumping behaviour from the neighbourhoods and industries upstream significantly degraded the population' health on the downstream Indonesian rivers [2]. Citarum river clean-up has been an effort, but this may work temporarily because piles of garbage will begin accumulating again as long as the old garbage-dumping habits continue [3].

One widespread effort in dealing with haphazard garbage dumping is using signs. Earlier studies on determining the effect of signs on garbage dumping behaviour, including using threatening messages, were adequate, primarily due to prior exposure, which is an important variable determining the effectiveness of signs [4]. However, these types of signs that work in advanced nations may not work in Indonesia. Kashima's study on the effectiveness of signs involves the psychological progression called the "sign-to-behaviour process" [5]. This theory suggests that encountering a sign, one uses a comprehension process, yearning to actions, leading to whether or not to comply. His studies confirmed that signs with specific purposes and practical implications/consequences proved to be effective. However, this work in advanced nations where people tend to be attentive to new signs due to law enforcement.

Dealing with garbage constitutes routine daily situations that force the people with hard choices and, for many, regularly dumping garbage haphazardly has led to this routine habit formation. This routine and habit formation idea is in line with social psychological theory, where psychological construct sustaining deep-seated attitude and behavioural patterns in established settings led to unacceptable habits, hampering any persuasion to adopt responsible behaviour, such as the right way of disposing of garbage [6]. This also follows a sociological perspective, where practices that have become habitual routine in a society becomes difficult to change due to the supporting situations, procedural, and acceptable discourses [7]. Thus 'habitual behavioural patterns' should be an essential construct for dealing with a haphazard garbage disposal in Indonesia. There is a need for functional changes in attitude and behaviour that requires an incremental transformation in routine habits based on these psychological and sociological approaches [8].

Since these theories might not work, due to the important emphasis of economic developments in Indonesia, Resosudarmo suggested comprehensive river water policies could help resolve the frightening environmental circumstances while maintaining economic growth [9]. However, his study lacks discussion of funding or resources needed for full effective implementation. Similarly, Sutrisno et al. described the significant challenges are limited campaigns leading to lack of legal awareness and insufficient enforcement of the environmental law resulting in the absence of legal compliance [10].

\section{Methods}

This study employed a multi-faceted socio-psychological analysis of behavioural change, discursive analysis of signs, and legal analysis of laws and policies. This is documentary research using the text of an academic article, hard news and opinions from printed and audiovisual media, books and articles as data sources. Data in news, interview, song lyric, regulation, and opinions are downloaded from the internet. It took two weeks to collect the 
data from the internet. We limit the news and interview that have been conducted since 2000 , considering that in 2000 , the campaign to ask Indonesian people to care about their environment increased. To collect the data, we use the keywords [menjaga lingkungan] 'to maintain environment', [pengelolaan sampah] 'waste management, and [polusi] 'pollution' in the search engine. We also used the key words [lagu tentang lingkungan] 'songs about environment' and [peraturan dan undang-undang tentang lingkungan] 'regulation about environment'. Of the various available data, we selected the relevant data containing the people traditional behaviour in managing waste. The data analysis unit is in the forms of words, clauses, and a group of clauses expressing the phenomena of managing dumping and the traditional behaviour relating to waste management. Data are analyzed using interpretative methods with the socio-cultural framing theories. An interdisciplinary approach is employed to discover the significances of the social phenomena described.

\section{Result and Discussion}

\subsection{Results: Challenges and the efforts of stopping haphazard waste-dumping}

The Indonesia archipelago comprising over 17,000 islands, is inhabited by a population with different beliefs and traditions. The close relationship between society and nature has been represented through various beliefs and traditions that can be traced in cultural events, artefacts, and language forms. Among them implies the traditional attitude of the Indonesian population in managing garbage dumping. For example, the Indonesian language has specific lexicons such as larung and bediang.

The literal meaning of larung is "to throw (something) overboard". However, larung is often associated with the cultural practice of throwing away bad luck or make sesaji. As an offering practice, larung is an immersive activity symbolized as throwing food, especially in the form of nasi tumpeng (cone rice) and its complementary flowers, fruits, another food material, and other complementary goods into the sea or rivers [11]. The material made for complimentary goods may be from plastic, paper, styrofoam sheets, and other nondegradable materials in this modern life. In particular community traditions, especially in the fishing community in Central Java, the items of sesaji is completed with buffalo head carcasses [12]. They usually throw five or seven buffalo head carcasses in the ceremony. The more head buffalo they throw, the more fortune they will get. They believe that if they get the abundant harvest, the number of buffalo heads offered (dilarung) should be more, hoping that the harvest or fish catch will be more abundant the following year.

Sometimes larung is also associated with specific beliefs. People throw certain goods, such as haircuts, nail clippings, heirlooms, and other unlucky objects, because they believe that the practice will keep them from bad luck. For a particular community, throwing the corpse ashes and the property of the corpse is believed to take the spirit to heaven faster. The properties will accompany his/her journey to heaven.

Articulating the cultural praxis, members of the society have socially shared knowledge that has been conceptualized cognitively as mental representation [13]. This is a knowledge that has been ideologically biased to control the belief and the activity of the members of society. As a belief, the shared knowledge about larung controls the way the members of the society think and behave. Putra explained that the inhabitant living around Ngebel lake in East Java believes that practising Larung sesaji in Ngebel lake must be held [14]. Otherwise, disaster will occur. Namely, the Ngebel lake water overflows and then drowns the surrounding community [14]. Then, the cultural praxis may construct another shared knowledge that throwing goods, even dumping, into the river, lake, or sea, is a natural act. 
They do not think that their habit causes polluted water. Changing their habit of littering the river, lake, or sea without revoking their tradition requires serious efforts.

The second traditional habit that damages the environment is bediang, a kind of bonfire. This is a habit of rural communities in Java to burn trash, livestock manure, coconut husk, dry grass, firewood, or other materials to repel mosquitoes or other small animals that bite their cattle. Smoke with a strong odor resulted from bediang is needed to repel mosquitoes. They were not bothered by the smoke. They also do not believe that the smoke can irritate their lung and that the smoke can pollute the environment. They believe that it is not dangerous because the habit has been made from generation to generation. The habit is practised by most of the farmers who have cattle. It has been the general shared knowledge stored in their long-term memories. Even the traditional farmers also have the habit of burning straws to start planting rice. The habit of preparing land by burning the straws and the remaining rice trees left in the field before planting rice has happened for decades. The farmers believe that it is a practical and cheap method, and it is believed to be a way to increase fertility. The burning method, indeed, can clear all plants immediately. However, this habit contributed to significant carbon emissions and repeated burning will cause the peat to disappear. Changing the habit from burning to not burning is not easy because they do not have sufficient knowledge, expertise or methods [15].

The accumulating challenges of the Indonesian waste are in line with economic development that encouraged urbanization, modern lifestyles and consumerism, supported technological progress leading to the production of non-biodegradable waste. Concern about these changes from organic biodegradable traditional materials such as woods and bamboo to modern industrial products such as plastics were expressed, for example, is a sad song by Franky and Janes in 1970's describing the paper and plastic products that have replaced the teak leaves:" Daun jati tak begitu laku lagi jawabnya, sebab kertas pembungkus, yang menggantikannya, di pasar desa (No one buys/uses teak leaves anymore, she answered, because the wrapping paper has replaced it, in the village market). At most significant issue here is that the drastic change was not followed by changes in garbage dumping and littering habits; nor was it followed by government regulation on dumping modern waste that can be toxic, especially for water sources in rivers.

Not until the 2000s was the government seriously concerned about the people's and communities' lack of awareness of this mounting modern garbage and came up with more comprehensive laws and regulations. The most significant one was when the Indonesian government issued a regulation on waste management and awareness campaigns. For example, Act number 18, 2008, article 29 stating that "Everyone is prohibited to a. carry in waste into the jurisdiction of the Republic of Indonesia; b. import waste; c. mix waste with hazardous and toxic materials; d. manage waste that causes pollution and environmental damage; e. dispose of waste improperly and haphazardly; f. handle waste through open dumping system at the final site, and g. burn waste by violating waste management technical specification."[16].

By the time these laws were implemented, the culture of littering and garbage dumping haphazardly into the rivers became routine for decades. The people usually do not obey the new law. One of the most common ways to deal with this dangerous and unhealthy habit is putting up signs in strategic places, including along the river banks. Although the government, organizations, and community groups come up with creative signs, people usually do not pay much attention due to routine and habit formation and the desensitization of any warning signs [17].

One of the most common signs is the one that says: "Dilarang buang sampah di sini," (No littering here). However, these signs often do not work, frustrating the local communities who came up with creative, attention-grabbing signs containing funny, religious, and threatening messages. A sign that says "Buanglah sampah pada tempatnya, pulangkan 
mantan pada orangtuanya" (Throw the garbage in its place [just like] returning your ex to her parents) was intended to be humorous but could be ineffective. Another sign that says: "Ya Allah cabutlah nyawa orang yang buang sampah di sini." (Oh God, take the lives of people whom litter/dump garbage here), more be sensitive to this religious population, but it is doubtful that it changes their behaviour. A more rational sign relies on legal consequences, stating: "Dilarang membuang sampah di sini, yang melanggar denda Rp.500,000." (No littering here, violator will be fined Rp500,000). Some other signs are threatening, but the effectiveness of which is questionable, such as "Dilarang buang sampah di sini, nanti tak tembak" (I will shoot anyone who dumps garbage here) [18].

\subsection{Discussion}

The traditional habit resisted in particular lexicons, the lifestyle influenced by the modernisation, and the weak implementation of regulation as found in the verbal data should get serious attention. Unfortunately, people have been desensitised because they have been continuously exposed to seeing warning signs of no littering with mounting trash surrounding them. Anyone going around Indonesia and reading mass -media will inevitably encounter familiar sights and images of piling trash in different roads and alleys of Indonesian cities, becoming part of the Indonesian socio-cultural landscape. These images show two important things that help build these images, lack of facilities and services.

The main reasons for haphazard littering and garbage dumping are the lack of services and facilities can be found from interviews published in social media such as the following. A men caught in the act of throwing garbage into a river were asked why he did this and his answer was"Kalo kita minta tolong petugas PU, tolong deh sampah menumpuk dekat rumah kita diangkat, kita nggak akan di dengar".... Pemerintah melarang kuta buang sampah di kali, tapi banyak sekali sampah di pinggir kali menumpuk tidak diambil PU".... Kenapa membiarkan sampah di pinggir kali” Kenapa buang sampah di Sungai? habis di buang ke mana? Ke tempat sampah? Dah penuh ngga ada yang ngambil. (When we ask for the officials help to pick up garbage piled up near our houses, they do not listen to us. The government forbid us from throwing garbage into the river, but there are already so much garbage at the river bank and they do not pick it up. But why would you dump the garbage in the river? Where else should we do it? How about garbage bin? There is none or the available one is full all the time and no one pick them up." [19]

The second issue is the lack of enforcement. As shown in another interview, a woman was asked if the people are aware of the municipal code article 2, 2013, and the fine of $\$ 500,000$ for violators, and she responded that they will always do it secretly because this is the most convenient way of garbage deposal, saying: "peraturan sih ada......., dendanya sih ada...., cuma orang masih buang sampah di sungai, kemana lagi?"... "sekarang dibersihin... nanti yang mbersihin pergi, ya buang lagi di situ" "soalnya belum ada yang ketahuan." (there is regulation... There is a fine for violators, but people continue to dump garbage into the river...where else? ...now they are cleaning it, but when the cleaning workers leave, the people will litter there again... because no one has been caught in the act).

The garbage-dumping habit has been deep-seated in the Indonesian people's culture, that there is an urgent need for drastic change. Following the habit formation above theory of 'habitual behavioural patterns' requires a gradual transformation in routine habits [8]. This can be done through education, campaigns, and organisational movements. For example, Community and youth organisations in Bali successfully convinced the local government to ban single-use plastic products and centralise garbage management, including pick-up and processing [20]. 


\section{Conclusion}

Generally, Generally, the analysis shows that the shared knowledge of Indonesian people regarding garbage management has been represented in their cultural activities as well as in their artefacts. Instead of maintaining traditions passed down, they have not realized that their activities may damage the environment. Other challenges in protecting the earth are the impacts of modernization and the lack of knowledge and consciousness about the importance of managing industrial waste. Indonesian people experience a change of lifestyle from using organic material to plastic material. Meanwhile, the government regulations to protect the environment have not been fully enforced.

Analyzing the personal opinion of residents in their social media regarding the implementation of the regulation concludes that the changes in these unacceptable routine habits require facilities and services and law enforcement. First, the government must invest significant funding and resources for facilities such as adequate garbage bins and services, including routine and frequent pick-ups set up for routine enabling residents to dispose of their wastes properly. Significant government's and community's commitment and investments of funding and resources should also be allocated in educations and campaigns to shape perception and beliefs on the importance of the environment for health. Second, the strict enforcement of the law requires active campaigns by functioning personnel supported by the uses of signs discussed above. While Creative use of signs can be ineffective and desensitizing, they are necessary as part of campaigning for the regulation and the enforcement of the laws. Signs containing legal consequences such as the details of the article and specific fines prove to be effective in changing unacceptable habits. This positive benefit should also include a healthy environment for the future generation.

\section{References}

1. M. Frances Prescott, Rivers as organisational structures: Evolving attitudes toward water in Jakarta, Indonesia, Abstract from European Association for Southeast Asian Studies Conference (EuroSEAS) 2-5 July 2013, Lisbon, Portugal (2013)

2. T. Garg, S.E. Hamilton, J.P. Hochard, E.P. Kresch, J. Talbot, J. E. E. M. 92, 53-53 (2018)

3. Cleaning up Indonesia's Citarum Basin, in Asian Development News and Events, October 2 (2014), Retrieved from https://www.adb.org/features/cleaning-indonesiascitarum-basin

4. S.M. Reiter, W. Samuel, J.A.S.P., 10, (1980)

5. J. Meis, Y. Kashima, P. O., 12, (2017)

6. W. Wood, D.T. Neal, Psy. Rev., 114 (2007)

7. P. Bourdieu, Outline of a theory of practice, 16, (Cambridge University Press Cambridge, 1977)

8. T. Kurz, B. Gardner, B. Verplanken, C. Abraham, WIREs Clim Change, 6, 113-128 (2015)

9. B.P. Resosudarmo, Int. J. E. S.D. 2 (2003)

10. E. Sutrisno, T. Sugiarti, N.A. Pratiwi, Int. J. S. T. R. 8 (2019)

11. K. Saddhono, K.R. Pertiwi, D. Anggrahini, A.S.S.E.H.R. 203 (2019)

12. S.U.M. Husnah, K. Agustin, R.I. Larasati, J.S.S.T. 3 (2019)

13. T.A. van Dijk, Discourse, knowledge and ideology: Reformulating old questions and proposing some new solution, in Paper LAUD, University of Amsterdam and Universitat Pompeu Fabra, second version (2002) 
14. T.A.H. Putra, A. Tinus, N. Yusuf, J.C.H. 2 (2017)

15. E. Nur Nirmala Sari, Peluang dan tantangan pertanian padi berkelanjutan di lahan gambut, in Mongabay (2020)

16. Act of the Republic of Indonesia number 18 year 2008, Retrieved from http://www.vertic.org/media/National\%20Legislation/Indonesia/ID_Waste_Manageme nt_Act_2008.pdf

17. R. Rahman, Those who litter here are monkeys': Greater Jakarta's litterbugs defy threats, warnings, in The Jakarta Post.com. November 3 (2018).

18. T. Rizqi, (2020), Percuma kalua berpendidikan tapi buang sampah sembarangan ups, Retrieved from https://www.brilio.net/ngakak/25-spanduk-lucu-imbauan-buangsampah-ini-pesannya-nyeleneh-201008u.html

19. Ini alasan membuang sampah di sungai, Video, Retrived from https://www.youtube.com/watch?v=grKN16Sw210

20. J. Augustin, In Bali young people lead the fight as the plastic plague threatens paradise, in Mongabay (2020) 